\title{
Solvent Problems in First Purex Cycle
}

by

H. P. Holcomb

E. I. du Pont de Nemours and Company

Savannah River Site

Aiken, South Carolina 29808

\section{INFORMATION ONLY}

\author{
DISCLAIMER
}

This report was prepared as an account of work sponsored by an agency of the United States Goyernment. Neither the United States Government nor any agency thereof, nor any of their employees, makes any warranty, express or implied, or assumes any legal liability or responsibility for the accuracy, completeness, or usefulness of any information, apparatus, product, or process disclosed, or represents that its use would not infringe privately owned rights. Reference herein to any specific commercial product, process, or service by trade name, trademark, manufacturer, or otherwise does not necessarily constitute or imply its endorsement, recommendation, or favoring by the United States Government or any agency thereof. The views and opinions of authors expressed herein do not necessarily state or reflect those of the United States Government or any agency thereof.

DOE Contract No.

This paper was prepared in connection with work done under the above contract number with the U.S. Department of Energy. By acceptance of this paper, the publisher and/or recipient acknowledges the U.S. Government's right to retain a nonexclusive, royalty-free license in and to any copyright covering this paper, along with the right to reproduce and to authorize others to reproduce all or part of the copyrighted paper. 


\section{DISCLAIMER}

Portions of this document may be illegible in electronic image products. Images are produced from the best available original document. 


\section{INTER-OFFICE MEMORANDUM}

Savannah River Plant

DPSP $-88-272-43$

March 30,1988

TO :

C. W. JENKINS, $221-\mathrm{F}$
Purex

First Cycle

Solvent

TBP

Uranium

Contamination

Solvent Washing

FROM: H. P. HOLCOMB, $772-\mathrm{F}$ HP

\section{SOLVENT PROBLEMS IN FIRST PUREX CYCLE}

\section{INTRODUCTION AND SUMMARY}

Last week, the first Purex cycle suffered uranium contamination of the solvent, $30 \%$ TBP in n-paraffin. Initial indication of maloperation was uranium contamination of the plutonium product stream, 1BP.

Uranium in relatively large quantities, $10^{-3}$ to $10^{-4} \mathrm{~g} / \mathrm{L}$, was found in the solvent in Tank 14.7. This tank contains first cycle solvent that has been through the solvent washing system and is destined for return back to the cycle. Solvent, contained in Tank 14.7 under normal operating conditions, has $<1 \times 10^{-4} \mathrm{~g} \mathrm{U} / \mathrm{L}$ following the carbonate-acid-carbonate washing sequence.

Tests conducted in the Separations Technology Laboratory and at SRL by $D$. J. Reif indicate that the current solvent problem is probably due to ineffective washing in the process since the solvent chemistry appears to be normal otherwise. Uranium in the contaminated solvent was easily stripped by single contacts with either $4 \%$ sodium carbonate or with 0.1 Mitric acid, the former being more effective.

The uranium content of the solvent was also reduced in the laboratory to very acceptably low values, mid $10^{-5} \mathrm{~g} \mathrm{U} / \mathrm{L}$, or 1 ess, by simulating the single batch contacts of the carbonate-acid-carbonate cycle. The interfacial tension of the Tank 14.7 material so treated was 4.3 as determined by Laboratories.

Work at SRL showed that the interfacial tension of the contaminated solvent, as sampled, was 2.5 , indicating that substances, possibly long chain acids, were present that could affect disengaging times for the solvent. Virgin 30\% TBP in n-paraffin has a interfacial tension of around 10 or better, for example. Tests conducted by Reif also showed that the contaminated solvent picked up signifi- 
DPSP $-88-272-43$

C. W. JENKINS

Page 2

March 30,1988

cantly more fission products, Ru106 and $\mathrm{Zr} 95$, than did virgin solvent. The contaminated solvent, following contact with alumina, had a greatly improved interfacial tension of 9.5 and exhibited much less pickup of both $\mathrm{Ru}^{106}$ and $\mathrm{Zr}^{95}$. In a H-Area process testing, contact of process solvent with alumina produced improved interfacial tension values and reduced $\mathrm{Zr} 95$ pickup by the $7.5 \%$ TBP used there.

From these tests, it is concluded that the contaminated solvent resulted from inefficient washing in the solvent washing system for first Purex cycle. Nominal solvent chemistry should result if the solvent is properly washed in the carbonate-acid-carbonate process cycle.

However, attention and study should be given to this solvent system because of the decline of its interfacial tension values. Such deterioration in solvent quality could be a portent of problems to come. Treatment with alumina, as was done with H-Area solvent, may become necessary.

\section{EXPERIMENTAL AND DISCUSSION}

Tank 14.7 Sample Used In Sep Tech Lab Tests

During the process upset, several Tank 14.7 samples were taken and analyzed by Laboratories Department for their uranium content. A series of 3 samples, taken $3 / 23$, contained $1.1 \times 10^{-3} \mathrm{~g} \mathrm{U} / \mathrm{L}$, one of the highest values found in the solvent. These samples were Lab 非49143, 非9144, and 非49145. For our work, 49143 and 49144 were combined in a composite sample, so each test solution taken therefrom was identical.

Equilibration of Solvent with $0.1 \mathrm{M} \mathrm{HNO} 3$ or with $4 \% \mathrm{Na}_{2} \mathrm{CO}_{3}$

A 5-mL aliquot of the composite was placed in a 30-mL graduated centrifuge cone and $5 \mathrm{~mL}$ of $0.1 \mathrm{M} \mathrm{HNO} 3$ added. The two phases were vortex mixed for two minutes then centrifuged to ensure good phase separation. In all of these tests, there was comparatively rapid phase separation following mixing. The aqueous phase was removed and reserved for uranium analysis. To the same organic was added a fresh $5-\mathrm{mL}$ aliquot of $0.1 \mathrm{M} \mathrm{HNO}_{3}$ and the procedure repeated. Finally, the organic was contacted with a third aliquot of acid.

The above procedure was repeated with a fresh 5 -mL aliquot of the Tank 14.7 composite, except $4 \% \mathrm{Na}_{2} \mathrm{CO}_{3}$ was used. Again, the same organic was washed with three fresh portions of aqueous.

All aqueous wash samples were analyzed for uranium by Labs using the Scintrex procedure. Table 1 lists the results of the analyses. 
DPSP $-88-272-43$

C. W. JENKINS

Page 3

March 30, 1988

TABLE 1

STRIPPING OF URANIUM FROM SOLVENT WITH HNO3 3 OR WITH $\mathrm{Na}_{2} \mathrm{CO}_{3}$

g U/L

$\mathrm{HNO}_{3}$ Washes

First

$6.5 \times 10^{-4}$

Second

$2.0 \times 10^{-4}$

Third

$6.1 \times 10^{-5}$

Total

$9.1 \times 10^{-4}$

$\mathrm{Na}_{2} \mathrm{CO}_{3}$ Washes

First

$1.0 \times 10^{-3}$

Second

$3.5 \times 10^{-5}$

Third

$9.8 \times 10^{-6}$

Total

$1.0 \times 10^{-3}$

Since equal volumes of organic and aqueous were used in the tests, no dilution factor or other correction is involved in comparing the total quantity of uranium stripped versus what was in the organic to begin with; i. e., $1.1 \times 10^{-3} \mathrm{~g} \mathrm{U/L}$. The data show that $59 \%$ of the uranium was stripped in the initial contact with $0.1 \mathrm{M} \mathrm{HNO}_{3}$ and that $83 \%$ of the uranium was recovered by contact with 3 portions of fresh acid.

For the carbonate washes, $91 \%$ of the uranium was recovered in the first wash with essentially the same percentage recovered as the total since the uranium content of the second and third carbonate washes was so low.

Washing Tank 14.7 Solvent Using the Carbonate-Acid-Carbonate Sequence

A 4-mL aliquot of the Tank 14.7 composite was similarly treated, except it was successively washed with $4 \mathrm{~mL}$ of $4 \% \mathrm{Na}_{2} \mathrm{CO}_{3}, 4 \mathrm{~mL}$ of $0.1 \mathrm{M} \mathrm{HNO}_{3}$, and then a final wash with another $4 \mathrm{~mL}$ portion: of $4 \% \mathrm{Na}_{2} \mathrm{CO}_{3}$. This sequence simulates what should happen during normal process washing of first cycle solvent. All aqueous washes were again analyzed by Labs using Scintrex. Table 2 reports these results. 
DPSP $-88-272-43$

C. W. JENKINS

Page 4

March 30,1988

\section{TABLE 2}

SOLVENT WASHING WITH CARBONATE-ACID-CARBONATE CYCLE

\begin{tabular}{|c|c|}
\hline & $\mathrm{g} \mathrm{U} / \mathrm{L}$ \\
\hline First wash, $4 \% \mathrm{Na}_{2} \mathrm{CO}_{3}$ & $1.2 \times 10^{-3}$ \\
\hline Second wash, $0.1 \mathrm{M} \mathrm{HNO}_{3}$ & $6.3 \times 10^{-5}$ \\
\hline Third wash, $4 \% \mathrm{Na}_{2} \mathrm{CO}_{3}$ & $5.9 \times 10^{-5}$ \\
\hline Total & $1.3 \times 10^{-3}$ \\
\hline
\end{tabular}

In this test simulating washing of first cycle solvent, essentially all of the uranium was stripped by the first carbonate wash. This quantitative stripping effect was like that found in the first of the 3 successive carbonate washes reported above.

Material balances for these tests are considered to be quite good, realizing the precision of the Scintrex method used for all analyses, including the original organic solvent that was uranium contaminated.

Therefore, from these tests, the uranium is not being bound in the solvent by some unusual chemistry; it is quite strippable and should be removed by the process washing system if it is operating properly.

\section{Interfacial Tension of Solvent}

The organic resulting from the above carbonate-acid-carbonate washing sequence was given to Laboratories for determination of its interfacial tension. Interfacial tension is a relative measure of quality and replaces the old disengaging ratio test. Solvent quality improves with increasing interfacial tension.

The interfacial tension of the solvent, after washing under conditions simulating first cycle treatment, was 4.3. Prior to solvent contamination by uranium, Laboratories had measured the interfacial tension of Tank 14.7 material, sampled $3 / 21$, to be 2.9 .

\section{SRL Tests}

A second composite sample of the contaminated solvent was prepared by combining Lab samples \#49310 and \#49316, both sampled late $3 / 23$, and $\# 49327$, sampled early 3/24. These samples contained $3 \times 10^{-4} \mathrm{~g} U / \mathrm{L}$. This composite was sent to D. J. Reif of ATD, SRL, for examination. 
DPSP $-88-272-43$

C. W. JENKINS

Page 5

March 30,1988

His initial test determined the interfacial tension of the sample to be 2.5 , close to the 2.9 value by Labs for similar solvent. After contacting a portion of the solvent with alumina, he redetermined the interfacial tension to be 9.5 , quite close to that of virgin $30 \%$ TBP in n-paraffin. Therefore, the "do-bads" causing the lowering of the interfacial tension were essentially removed by contact with alumina, but only minimally by the carbonate-acidcarbonate washing cycle.

Another test he conducted was how well the solvent extracted fission products, Ru106 and $\mathrm{Zr} 95$, the so-called "Pickup Test". The following table indicates the results of this test.

TABLE 3

SOLVENT PICKUP TEST COMPARISONS

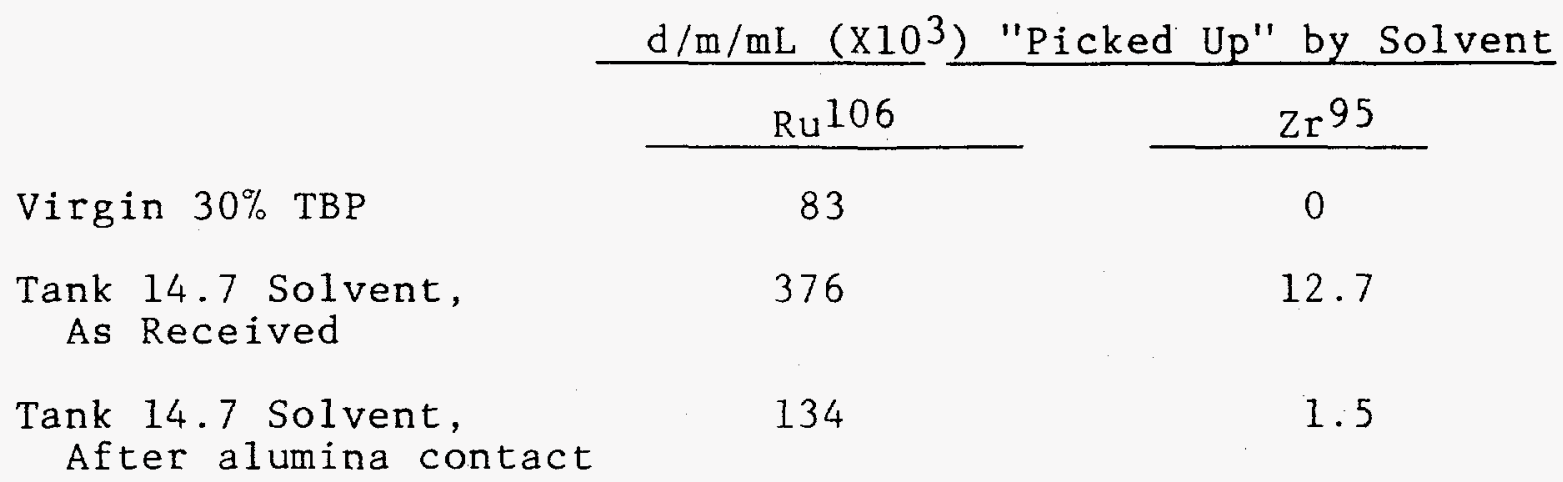

The solvent, as sampled from Tank 14.7, exhibited significantly increased fission product retention over that of virgin material. However, after a single contact with alumina, these retention properties were reduced to almost that of fresh, unused $30 \% \mathrm{TBP}$ in n-paraffin.

\section{CONCLUSIONS}

The solvent in Tank 14.7 was contaminated with uranium. The use of this solvent on return to cycle was causing problems by contaminating the product with uranium.

The uranium can be readily and easily stripped from the solvent: by either washing with dilute sodium carbonate or with dilute nitric acid. Washing with the carbonate-acid-carbonate sequence, simulating first cycle solvent washing, depleted uranium values in the solvent to very acceptable values for return to process. 
DPSP $-88-272-43$

C. W. JENKINS

Page 6

March 30,1988

SRL tests indicated that the solvent did have a low interfacial tension, 2.5, similar to Laboratories'value. The contaminated solvent suffered also from increased pickup of fission products. However, a single contact with alumina not only increased the interfacial tension to almost that of virgin $30 \%$ TBP in $n$-paraffin, but also greatly reduced its affinity for Ru106 and $\mathrm{Zr} 95$.

If the solvent were being effectively washed in the process solvent washing system, it should be expected to function normally in Purex first cycle.

However, the reduction in interfacial tension values from values of 7-8 in December and January to the latest, 4.3, which was measured on Tank 14.7 material on $3 / 30$, indicates deterioration of solvent quality. This situation needs further attention and study to prevent possible processing problems later on.

\section{ACKNOWLEDGMENTS}

The excellent cooperation and timely interest shown by D. J. Reif, SRL, are most appreciated. His tests assisted in confirming the solvent quality, as received, to be abnormal, but remediable.

I wish to recognize the excellent work done by the Laboratories' 772-1F shift personnel in determining, by Scintrex, the uranium values of our test solutions. S. B. Danforth assisted by coordinating these efforts.

P. B. Berry of Labs and his technicians conducted the interfacial tension measurements for us. Their work was also instrumental in helping to quantify the quality of the solvent.

$\mathrm{HPH} / \mathrm{h}$ 